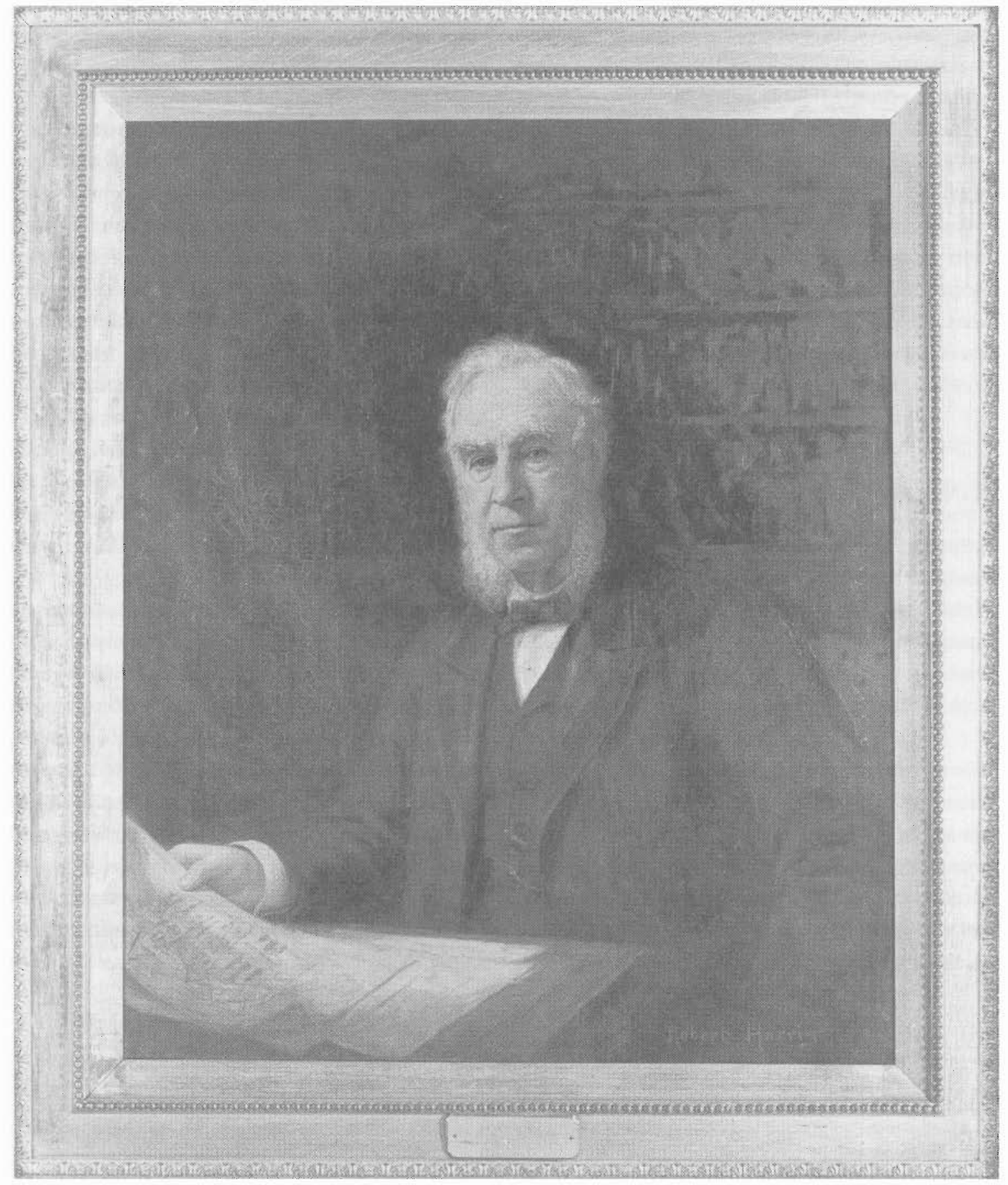

Figure 1. Peter Redpath. 


\section{PETER AND GRACE REDPATH: COLLECTORS AND BENEFACTORS}

\section{By Peter F. McNally}

Peter Redpath (1821-1894) and his wife, Grace Wood Redpath (1816-1907), played a significant but largely forgotten role in Canadian cultural development. They were Canada's first major benefactors of libraries and museums and among the country's first benefactors of higher education. Grace was the first woman to be a significant benefactor of a library, museum, or university in Canada. The Redpath Museum and Redpath Library buildings are visible reminders of their contribution to McGill University. The Library was the first specifically-designed library building in Quebec. The Redpaths also made important contributions of books and gave substantial endowments to McGill, whose income continues to benefit students and researchers.

Peter Redpath (1821-1894) et sa femme, Grace Wood Redpath (1816-1907), ont joué un rôle notoire, encore que largement oublié dans le développement culturel du Canada. Is ont été les premiers grands bienfaiteurs des bibliothèques et des musées du Canada et parmi les premiers bienfaiteurs de l'enseignement supérieur au pays. Grace a été la première bienfaitrice d'une bibliothèque, d'un musée ou d'une université au Canada. Les pavillons du Musée et de la Bibliothèque Redpath sont des rappels bien vivants de leurs précieuses contributions à l'Université McGill. La Bibliothèque a été la première bibliothèque expressément concue comme telle au Québec. Les Redpaths ont également fait don de nombreux livres et d'importantes dotations à l'université, don't les revenus continuent de profiter aux étudiants et aux chercheurs.

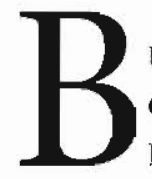

URIED ON THE GROUNDS of St. Nicholas Church, Chislehurst, Kent, in south-east England, are two eminent Canadians: Peter and Grace Redpath. The tall Celtic cross surmounting the flat memorial embedded in the ground, marking their final testing place, is to the right of the lychgate as one enters the churchyard: forty feet from Church Lane and twenty feet from the pathway leading to the church's south porch.

Despite his entry in Britain's Dictionary of National Biography, Peter Redpath (Fig. 1) is largely forgotten today; ${ }^{1}$ he has not even received an entry in the Dictionary of Canadian Biography. As for Grace
Redpath, she has always been a shadowy figure, about whom little is known. Attempts to reconstruct the details of their lives and provide coherent biographies, fixing their personalities and characters, and establishing their historical contributions, are thwarted by a paucity of surviving records and reminiscences. Concerning their lives in Chislehurst, where they spent their final years, next to nothing is known, least of all their reasons for settling there.

Yet the Redpaths are of continuing importance in Canadian cultural history for having been among the most important collectors and benefactors of their time. The positive benefits of their efforts remain

1 Charles Alexander Harris, "Peter Redpath," in Dictionary of National Biography (London: Oxford University Press, 1921-1922), XVI: 827-28; "Peter Redpath (1821-1894)," in A Standard Dictionary of Canadian Biography, ed. Sir Chasles G.D. Roberts (Toronto: Trans-Canada Press, 1938), II: 372-73. 
visible today, at McGill University in Montreal, Quebec where Redpath Museum and Redpath Library still stand. Redpath Museum was the first specificallydesigned museum building in Canada, while Redpath Library was the first specifically-designed library building in Quebec and the second academic library building in Canada. In addition to constructing these two buildings, the Redpaths made significant contributions of books that rank among the most important research collections of any Canadian academic library. Finally Peter, Grace, and other Redpath family members gave substantial endowments to McGill, whose income continues to benefit students and researchers. These benefactions, however important to McGill University and the Province of Quebec, confer upon Peter and Grace the distinction of being Canada's first significant museum and library benefactors and among the country's first great benefactors of higher education. The purpose of this paper will be, therefore, to give a brief biographical sketch of Peter and Grace Redpath, an indication of how their lives and benefactions intertwined, and some sense of the nature and significance of these benefactions.

If the details of their lives, including their reasons for settling in Chislehurst, are uncertain, the broad outlines are reasonably well known. Peter Redpath was born on August 1, 1821 in Montreal, where he received his early education. In 1837, at the age of sixteen, he was sent by his father to Engiand to complete his education and learn business practice in Manchester. One assumes that this is when he first met Grace Wood, who was born on May 21, 1816 and lived in Bowden (sometimes spelt Bowdon), Cheshire, near Manchester. After marrying on Octo- ber 16,1847 they lived in Montreal but travelled widely before buying the Manor House in Chislehurst and settling there permanently in the 1880s. On February 11, 1894 Peter died, and thirteen years later Grace died on January 30,1907 . A number of general characteristics can be ascribed to the Redpaths: they shared a strong patriotic and cultural attachment to Britain; they were profoundly religious; and they compensated for their lack of children by cultivating close relationships with a bevy of nephews and nieces and by becoming collectors and philanthropists.

It is uncertain whether Peter Redpath's values and interests developed in conformity with or in reaction to those of his family. His father was John Redpath (1796-1869) a Scottish stone mason who in 1816 , aged twenty, immigrated to Canada as it was entering a period of great economic growth following the Napoleonic Wars. ${ }^{2}$ He soon made a fortune as a contractor of great building projects such as the Lachine Canal, the Rideau Canal, and the Church of Notre Dame de Montréal. His fortune made, John Redpath became a leading member of the expatriate Scots community that dominated the economic life of Montreal and transformed it into Canada's metropolis. In 1833 he became a director, and in 1860 a vice-president, of the Bank of Montreal, Canada's oldest bank and also the largest well in to the twentieth-century. He also invested heavily in Montrealbased insurance, telegraph, mining, investment, and shipping companies, as well as in property. In the 1850 s he introduced the sugar industry into Montreal and Canada. Taken together, these activities placed John Redpath at the centre of the activities that propelled Montreal into becoming the hub of.

2 Gerald Tulchinsky, "Iohn Redpath," in Dictionary of Canodian Biography, vol. 9, 1861 to 1870 (Toronto: University of Toronto Press, 1976), 654-55; "John Redpath," in History and Biographical Gazetteer of Montreal to the Yeor 1892, ed. 1. D. Borthwick (Montreal: Lovell, 1892), 130 .

3 Newton Bosworth, Hochelaga Depicata: the Early History and Present State of the City and Island of Montreai ( Montreal: Greig, 1839; reprint, Toronto, n.p., 1974), 119-20, (page citations are to reprint edition); Elizabeth A. K. McDougall, "Edward Black," in Dictionary of Conadian Biography, vol. 7, 1836 to 1850 (Toronto: University of Toronto Press, 1988), 77-78.

4 Sir John William Dawson, in Memoriom, Peter Redoath, Governor and Benefoctor of McGill University and Founder of the Museum, Library and Chair of Mathematics which Bear His Name with Historical Notice of the Redpath Museum (Montreal: Witness Printing House, 1894), 5. 
manufacturing, transportation, and finance for British North America and eventually all of Canada.

A devout man, the elder Redpath was initially a member of St. Gabriel's, the largest Presbyterian congregation in Montreal. When, in 1832, disputes led to its splitting into separate congregations, he followed one of the ministers - the intensely emotional and evangelical Edward Black (1793-1845) who established St. Paul's Church. ${ }^{3}$ Along with Peter McGill and John Ross, equally eminent Montrealers of the day, Redpath became a trustee of the new congregation which soon built a church in the gothic style. Completed in 1834, for $€ 3,569$, St. Paul's vied in size with St. Gabriel's and was the first Presbyterian. church in Montreal to be designed by, John Wells, an architect newly-arrived from England. Adjacent to the church, there was constructed for $£ 436$, a school, where Edward Black also presided as teacher, and where Peter Redpath received at least some of his early education. Located at the comer of St. Helen and Recollet Streets, in what is now referred to as Old Montreal, St. Paul's School would later be described by McGill's Principal, Sir John William Dawson, as one of the best in Montreal. ${ }^{4}$

John Redpath was noteworthy in other aspects of his life. He served briefly on Montreal city council and on various provincial commissions. As a philanthropist he supported a wide range of activities, particularly those associated with the Presbyterian Church. In addition, he supported other causes and institutions such as the Montreal General Hospital, of which he was president from 1859 to $1868 .{ }^{5}$ Of particular interest was his appointment in 1840 as president of the re-established Montreal
Mechanics' Institute. ${ }^{6}$ Founded in 1828 , it was the second oldest institute in Canada based upon the principles of Sir George Birkbeck (1776-1841), the English educational reformer. In addition to giving courses, Montreal's Institute possessed a library and museum, harbingers of his son Peter's philanthropy. John Redpath married twice and had seven children by his first wife, and ten by his second. ${ }^{7}$

Peter, the first son and second child by the first wife Janet McPhee (1791-1834), was born in Montreal, at the time when his father was engaged in constructing Notre Dame de Montreal and the Lachine Canal. At least part of young Peter's childhood was also spent some distance from Montreal, at the village of Jones Falls in the Ottawa Valley, half-way between Kingston and Smiths Falls, Upper Canada (now Ontario) where John Redpath was constructing the Rideau Canal and "carving out the route from virgin forest, rocky wilderness, swamps, and lakes." ${ }^{8}$ The intelligence and force of character, which John Redpath obviously required in accomplishing these great projects, would have been central factors in the lives of Peter and his siblings. The challenge for all the Redpath children would be in developing lives for themselves, while at the same time fulfilling their father's expectations. In the case of Peter, he appears to have developed a knack for dealing with his father and other intelligent, strong-willed people, by deferring to their priorities and assisting them in fulfilling their ambitions, while at the same time carving out for himself a life of personal accomplishment.

With his profit of $£ 20,000$ from the Rideau Canal, John moved his growing family back to Montreal in 1831 and built a house costing $£ 5,300$ - an immense

\footnotetext{
5 E. . Shepherd, Origin and History of the Montreal Generol Hospital (Montreal: Gazette Printing, 1925 ), 2.

6 Atwater Libraly of the Mechonics' institute of Montreal (n.p., n,d, ); Nora Robins "The Montreal Mechanics' Institute, $1828-1870$," Candedian Library journal 38, no. 6 (December, 1981): 272-79.

7 Richard Feltoe, Redpoth: the History of o Sugar House (Toronto: Natural Heritage, 1991), 290-91. There is some confusion arnong the various sources concerning the number of child ren by each wite.

8 Feltoe, Redpoth, 28 .
} 
sum at the time. 9 The next few years brought great change to the Redpath family. On July 26,1834 , the year that St. Paul's Church was completed, Janet Redpath died in childbirth leaving her widowed husband with six children. ${ }^{10}$ A year later, in September 1835, the 39-year-old widower married the 20-year-old Jane Drummond (1815-1907), younger sister of his deceased partner Robert. The following year, John Redpath purchased an estate from the Desrivières family who were related to Mme Charlotte Desrivières, the wife of James McGill. The 235-acre estate, located on the southern slope of Mount Royal, just west of the McGill University campus, was mostly wilderness or pasture. Stretching from approximately Drummond St. on the east to Redpath or Simpson St. on the west, the estate extended north from below Sherbrooke St., up the slope of the mountain, over its crest, and finished only at the Protestant Cemetery, now Mount Royal Cemetery. ${ }^{11}$ The entrance to the estate was the northern corner of Sherbrooke and Mountain streets. For generations, Mountain St, north of Sherbrooke was called either Redpath Lane or Avenue. The centre-piece of the estate was a charming French Canadian house, which was likely used as a country retreat. Situated on the northern side of what is now lenfield Avenue between Mountain St. and Avenue du Musée, the present site of the Russian consulate - it would eventually be demolished to permit the construction of a large mansion befitting John's wealth and dignity. The estate became a major source of revenue for the family. Well into the twentieth-century building lots were sold-off, as sites for Square Mile mansions and other residences. Along with portions of other estates, part of the Redpath estate was sold to the city in the 1870 s to become Mount Royal Park. ${ }^{12}$ As vestigial remains of this once proud estate and a lingering reminder of the family's role in Montreal's urban development, there are Court, Crescent, Place, Row, and Street still bearing the Redpath name in the area west of McGill.

The Rebellions of 1837 precipitated further change in the Redpath family. ${ }^{13}$ Although John, who was a strong supporter of the Constitutional Association and the English-speaking-community of Lower Canada, remained in Montreal, he sent his new wife and children, except for Peter, to the rural tranquillity of Jones Falls to protect them from potential violence. As for Peter, he was withdrawn from St. Paul's School and sent to Manchester, England to complete his education and learn about business. This decision reflects the lack of educational opportunities available in early 19th century British North America. Although McGill University had received its charter in 1821 , it began its teaching program only in 1829 and then just in medicine. ${ }^{14}$ As for the suggestion that Peter was sent briefly to the United States for schooling, no evidence of this has been discovered. More likely, John considered that only in Britain could his eldest son receive the education and training suitable for his destined position in Montreal. Finally, one may legitimately wonder whether Peter, being much closer in age to his new stepmother than she to her middle-aged husband, may not also have played some part in sending him abroad.

9 Ibid., 29.

10 lbid., 29

11 James Cane, Topographical and Pictorial Mop of the City of Montreal (Montreal: MacKay, 1846), [Drawings by J. Duncan]; Roderick MacLeod, "Salubrious Settings and Fortunate Families: the Making of Montreal's Golden Square Mile, 1840-1895," (Ph.D. diss. , McGill University, 1997). Chapter 3 is particularly helpful, as are the maps.

12 Charles E. Beveridge, Frederic Law Oimsted, Designing the American Landscape (New York: Rizzoli, 1995), 88-90.

13 Feltoe, Redpath, 29, 34-35

14 Stanley Frost, McGill University for the Advancement of Learning, vol 1 (Montreal: McGill-Queen's University Press, 1980), chapters 3-4. 
If Montreal in the 1830 s and 40 s was a city of disturbances, unrest, and fundamental social change, Manchester was equally so. Although we may know little about Peter's life in Manchester, we know much about that city during these years. Synonymous with Victorian industrial might and prosperity, Manchester was a city of exaggerated discrepancies: on the one hand the rich and powerful, with their great public buildings, and on the other hand the poor and weak with their miserable dwellings, including basement housing for 40,000 to 50,000 people. This was in a city whose population grew from 182,000 in 1831 to 303,000 in $1851 .{ }^{15}$ Not surprisingly, a variety of responses arose in the face of the city's dynamic and stressful conditions. At the grass-roots level, there was Chartism - a radical working-class movement whose rhetoric was significantly more dangerous than its actions. In fact, its major aim was parliamentary reform and the extension of the franchise. As the site of the infamous 1819 Peterloo Massacre, Manchester's involvement in the Chartist movement is easily understood. The second major response from Manchester was decidedly optimistic and middle-class. ${ }^{16}$ The Manchester School was a political movement that aimed to end aristocratic control of the British government and related social-economic institutions; it was associated with laissez-faire economics, the Anti-Corn Law League, free trade, and the Reform Bills of 1832 , 1867 , and 1884 , which gave Britain universal male suffrage. The third major response of Manchester was to emphasize the importance of educational and cultural activities and institutions. These were exemplified in a wide range of libraries, museums, and concert halls, and in Owens College, founded in 1851, for the study of science and technology, and the progenitor of the University of Manchester. ${ }^{17}$ What impact did Manchester have upon Peter Redpath? Circumstantial evidence suggests that it must have been substantial enough to prompt his proposal to Grace Wood (Fig. 2) in 1845, and their subsequent marriage in Bowden on October 16, 1847. ${ }^{18}$

The Wood family is as notable and little known as the Redpaths. ${ }^{19}$ Grace Redpath's father was William Wood, a prominent Manchester businessman, well known for his philanthropy and opposition to the employment of boys as chimney sweeps. ${ }^{20}$ Her mother was a member of the Burton family, prominently associated with the Wesleyan revival and the building of the celebrated Oldham Street Wesleyan Church in Manchester. By the 1830s, the Woods were living in Bowden, one of the upper middle-class suburbs surrounding Manchester, well away from its inner city slums. At the age of 29 , Grace felt such a strong attachment to England, her family, and religion that she mentioned all three in her reply of July 18,1845 , to Peter Redpath's letter of proposal; she was particularly concerned to know if he would ever consider living in England. ${ }^{21}$ Their marriage, which appears to have been very happy, was obviously based upon shared values and interests, which they pursued vigorously and jointly. That she was both strong-willed and intelligent is clear. It is also clear that he did everything possible to permit them to live extended periods of their married life in England. It was well understood within the family that Grace, who was five years older than Peter but only one year younger than his

15 J. F. C. Harrison, Early Victorian Britain, 1832-51 (London: Fontana, 1988), 26-27, 67-68, $150-57$.

16 William D. Grampp, "Manchester School," in The New Polgrave: a Dictionary of Economics (London: Macmillan, 1987), 3: 296-97.

17 Peter Gay, The Bourgeois Experience: Victoria to Freud, vol.5, Pleasure Wars (New York: Norton, 1998), 75-89.

18 Dawson, in Memoriam Peter Redpoth, 7.

19 H. R. Morgan, "Mrs. Peter Redpath: a Generous Donor and Philanthropist," Saturday Night 41 (December 19, 1925 ), 27.

20 "Evidence as to the Violation of the Law Relative to the Employment of Climbing Boys in Sweeping Chimneys" Children's Employment Commission (1862) in First Report of the Commissioners for Inquiring into the Employment and Condition of Children in Mines and Manufactaries (Eyres \& Spottiswoode, 1863), 295-97. Included is evidence from Mr. William Wood of Bowden. 


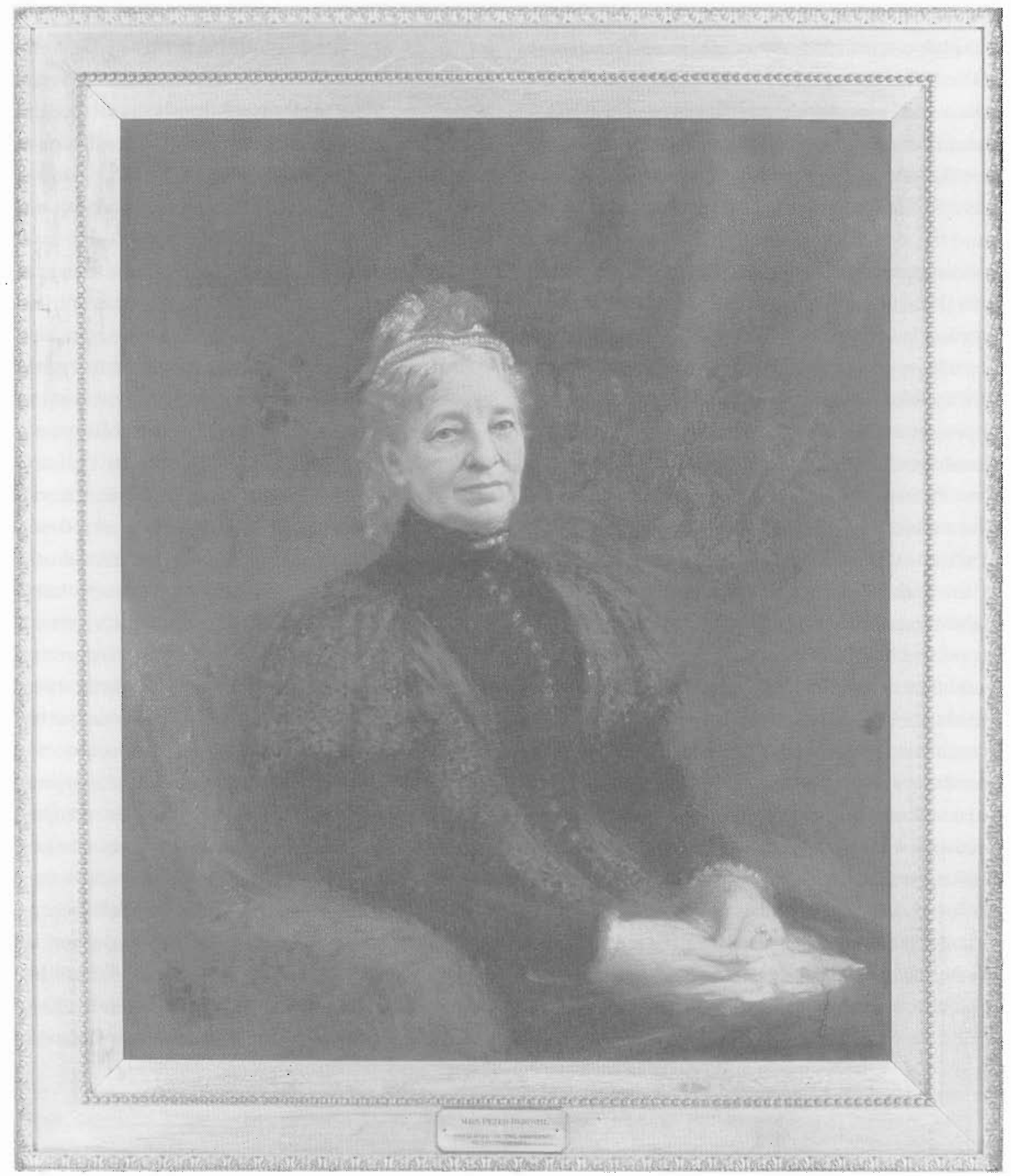

Figure 2. Grace Redpath (née Grace Wood). 
step-mother, Jane Redpath, did not get along with John's second wife, who now became her motherin-law. This situation may also account for Peter and Grace spending so much time in England.

Before proceeding further, it is important to appreciate that Peter and Grace shared an important bond other than their upper middle class family backgrounds. They were both religiously non-conforming, which is to say that they were not members of the established Church of England. Peter was a Presbyterian and Grace a Methodist. Much of the leadership for parliamentary reform in Victorian Britain came from people of similar non-conformist backgrounds. In fact some historians have hypothesized that the maintenance of British political stability in the nineteenth century was dependant upon integrating the non-conformist community into the political mainstream. As we will see, Peter and Grace played an important role in memorializing how this process of political reform was accomplished. ${ }^{22}$

Although Peter appears to have held a special place in his father's affections, it is intriguing to note their dissimilarities as well as their similarities. They were both equally devoted to Presbyterianism and their families; they were both collectors; and their activities focused upon philanthropy and business. Yet in these as in other matters they displayed very different approaches. As a business man, Peter seems to have been content to follow in his father's footsteps, even sitting on the board of directors of many of the same companies. Indeed, upon returning to Montreal from Manchester in 1845, he entered the firm of Dougall, Redpath, \& Co. There is little evidence of his being an entrepreneur or developing any new business ventures, with the possible exception of some mining and property investments in the Canadian
Prairies, then called the North-West. Peter's ambivalent attitude towards his father's values came to a head in the 1850 s and 60 s when he joined the sugar company at John's request, while at the same time becoming a book collector and a benefactor of McGill University. In short, John was primarily a businessman who also practiced philanthropy; by contrast, Peter was primarily a philanthropist who also practiced business. John collected money and company directorships; Peter collected books and historical recognition for the family. John made the money and Peter spent it. John was twice married with seventeen children whereas Peter remained childless through one marriage. Yet rather than seeing these variations as points of opposition between father and son, perhaps they should be seen as part of the natural evolution of the Montreal business elite during the nineteenth-century.

Montreal began the century as a town of 9,000 people and ended it as Canada's largest city with a population of $328,172 .{ }^{23}$ Although various considerations prevented it from becoming Canada's political capital, it soon emerged as the economic and cultural capital. By the century's end, it is estimated that the city controlled between two-thirds and three-quarters of the wealth of the new nation created by Confederation in $1867 .{ }^{24}$ Of this wealth, the bulk was controlled by English-speaking Protestants, a high proportion of whom were Scots Presbyterians. Despite there being an English-speaking majority during the middle decades of the century, the prevailing ethos of Montreal, like that of the Province of Quebec, remained French-speaking and Roman Catholic. Responsibility for the social and educational needs of the Francophone community was assumed by the Church. As for the Anglophone community's social

21 Redpath Sugar Refinery Archives, Toronto.

22 To be amplified in a forthcoming study.

23 G. R. Lomer, "Montreal," in Encyclopedia Canadiana (Toronto: Grolier, 1972), 7: 138-48.

24 Margaret W. Westley, Remembrance of Grandeur: The Anglo Protestant Elite of Montreal, 1900-1950 (Montreal: Libre Expression, $1990), 7$. 
and educational needs, their responsibility fell to its elite. By century's end, this elite resided primarily on the southern slopes of Mount Royal, on properties surrounding and even carved out of the Redpath estate, in an area referred to as the Square Mile, or sometimes the Golden Mile. In American history, the possessors of such concentrations of wealth are referred to as robber barons; in Canadian history they are referred to as merchant princes. ${ }^{25}$ The merchant princes and their descendants soon developed social consciences and aesthetic concerns. Great private collections developed and Canada's first specifically designed public art gallery opened in Montreal in 1879, ${ }^{26}$ Support for social and educational institutions became equally generous.

One of the primary institutions to vie for the support of the merchant princes was McGill University. Founded by Royal Charter in 1821 and pedagogically active from 1829 , McGill was little more than a struggling backwoods college when John William Dawson (1820-1899) became principal in $1855 .{ }^{27}$ One of the great scientists of the century and Canada's leading intellectual, Dawson was later knighted (KCMG) for transforming McGill into the leading Canadian university, with a growing international reputation, during a tenure lasting until 1893. As McGill could never count upon adequate government support from Quebec's Francophone Catholic majority, private benefaction from Anglophone Protestants was the oniy alternative. Cultivating the support of the Montreal business community became, therefore, an early preoccupation of Dawson. Of all the people whom he cultivated,
Dawson's greatest success was undoubtedly with Peter Redpath. Not only did Peter become one of the most important benefactors of Dawson's principaiship, but the two men also developed a close personal friendship. Indeed, Dawson would eventually become Peter Redpath's biographer. ${ }^{28}$ Peter was attracted to intelligence and force of character, but would also ensure his own self-fulfillment while assisting Dawson in fulfilling his priorities.

It was within this social, economic, and familial setting that one must attempt to piece together the details of Peter and Grace Redpath's lives and how they became collectors and benefactors. Peter's marriage in 1847 to Grace Wood coincided with a serious depression in the Canadian economy, occurring at the same time as the victory in Britain of the Anti-Corn League in $1845 .{ }^{29}$ The League's victory which was also a Manchester School victory resulted in British free trade, which ended the preference hitherto given to Canadian wheat. Trade between Britain, Canada, and the other British colonics had previously been regulated by mercantile laws and Navigation Laws, which granted reciprocal privileges and restrictions within the empire: preferential access to markets and the controlled transportation of such trade. Although the mercantile laws granting preference were repealed, the Navigation Laws controlling transportation remained in force until 1849/50. This situation left the Canadian economy momentarily vulnerable to American economic might. The financial losses that these events brought to John Redpath, and other Montreal businessmen, resulted in 1849

25 Donald Mackay, The Square Mile: Merchant Princes of Montreol (Vancouver: Douglas \& McIntyre, 1987).

26 Janet Brooke, Discerning Tastes: Montreol Collectors, $1880-1920$ (Montreal: Montreal Museum of Fine Arts, 1989).

27 Peter R. Eakins, "Sir John William Dawson," in Dictionary of Canadian Biography, vol. 12, 1891 to 1900 (Toronto: University of Toronto Press, 1990), 230-37; Thomas G. Bonney, "Sir John William Dawson," in Dictionary of National Biography (London: Oxford University Press, 1921-1922), XXII: 545-47.

28 See footnote $\# 4$

29 W. T. Easterbrook, Canadian Economic History (Toronto: Macmillan, 1956), 368; Gilbert N. Tucker, The Canadion Commerciol Revolution, 1845-1851 (Toronto: McClelland and Stewart, 1964), 63-64, 154; Gerald Tulchinsky, The River Barons: Montreal Businessmen and the Growth of industry and Transportation, $1837-53$ (Toronto: University of Toronto Press, 1977). 
in political unrest and his becoming president of the Montreal Annexation Association that advocated Canada becoming part of the United States. ${ }^{30}$ The movement was short-lived, however, and died out a few years later, but not before the burning down of the Parliament buildings in Montreal ended its ambition of retaining permanently its status as Canada's capital. More importantly for our story, these events inspired John Redpath to consider investing in some type of mamufacturing that would ensure his family's financial future. In the end he decided upon sugar refining as it lacked any competition within British North America, despite being one of the biggest imports. ${ }^{31}$ In 1850 , he visited Britain and studied refineries in England and Scotland, ${ }^{32}$

John's decision to open a refinery was critical in many ways: it involved a huge outlay of capital, it was the first permanent sugar refinery in Canada, it spearheaded Montreal's conversion from a trading to an industrial city, and despite periodic setbacks it provided an enormous boost to the family fortune. Throughout its existence, the refinery was notable for several things: its dependence upon protective tariffs, its technological innovation, its strong leadership, and its profitability.

In 1853 , John began buying property along the Lachine Canal, which he had helped to build from 1821 to 1826 , and which had undergone a major expansion between 1843 and $1848 .{ }^{33}$ John Ostell, the architect of McGill's Arts Building, designed a refinery whose construction began immediately. Also in 1853, Peter and Grace accompanied his father to Britain to purchase the machinery for the new factory, which began production on August $12,18544^{34}$ The role played by peter Redpath in the development, growth and profitability of the sugar refinery was enormous; from the beginning, he worked directly with his father in its planning, organization and operation. After the opening, he worked so diligently that in 1857 the refinery's corporate name was changed to John Redpath \& Son, Canada Sugar Refinery. Although other sons and family members became involved in the business, their contribution was never sufficiently large to warrant "Son" becoming "Sons." 35 There was, however, another individual connected with the refinery whose contribution would eventually eclipse Peter's. This was George Alexander Drummond (1829-1910), a graduate of the University of Edinburgh and the son of the man under whom John Redpath had apprenticed as a stone mason. ${ }^{36}$ Drummond came to Montreal in 1854 to become the refinery's manager. In addition to his undoubted financial and administrative genius, Drummond's involvement with the business was also famitial. He was the brother of Jane, the second wife of John Redpath. ${ }^{37}$ Moreover, in 1857 George married Helen Redpath (1827-1883) a sister of Peter and the fifth child of John. In time, Drummond would become a senator of Canada, knighted (KCMG and KCVO) and president of the Bank of Montreal (1905-1910).

30 The Annexation Manifesto of 1849. Reprinted from the Original Pomphlet with the Names of the Signers (Montreal: D. English, 1881), (microfiche); Kathleen lenkins, Montreal, Island City of the St. Lowrence (New York: Doubleday, 1966), Chapter 28.

31 Fernand Ouellet, Ecanomic and Socioi History of Quebec, 1760-1850 (Toronto: Macmillan, 1980), 677.

32 Redpath: One Hundred Years of Progress, 1854.1954 (n.p., n.d.).

33 Cerald Tulchinsky, "The Construction of the First Lachine Canal, 1815-1826" (Masters thesis, McCill University, 1960), Chapters $7-8,111$.

34 Feltoe, Redpoth, $39-43$.

35 bid., 30 .

36 Michèle Brassard, "Sir George Alexander Drummond," in Dictionary of Canadian Biography, vol. 13. 1901 to 1910 (Toronto: University of Toronto Press, 1994), 283-84.

37 There is confusion among the various sources as to whether George and jane were brother and sister or nephew and aunt. 
He also became a distinguished art collector. George Drummond is the fourth and final person of intelligence and strength of character with whom Peter would have dealings in this story.

Although, in some years, the refinery would show low profits and even occasional losses, the trajectory was generally one of growing profitability, despite the appearance of competitors in Montreal and other parts of the country. By 1859 , after only five years of operation, the value of the assets had grown from an initial investment of $£ 40,000(\$ 200,000)^{38}$ to $\$ 285,749.72$ with profits for the year of $\$ 89,546.98$. In 1860 , profits rose to $\$ 111,868.06 .^{39}$ As the refinery was clearly in need of a more sophisticated administrative structure to cope with its expanding activities, articles of partnership were drawn up that same year giving John sixteen and Peter five of twenty-one shares. Provision was made to admit George Drummond and the younger Redpath sons as partners, should they so wish. ${ }^{40}$

Indicative of the refinery's profitability was John's replacing of the old Desrivières house on his Mount Royal estate in 1861 with an impressive mansion. "Terrace Bank", designed by the local architect J. W. Hopkin, was constructed of undressed limestone in an eclectic and asymmetrical Victorian style, with an imposing tower. ${ }^{41}$ In addition to accommodating a large family, the house was clearly intended to impress the world. In 1862, new partnership articles were drawn up dividing the twenty-one shares as follows: John Redpath eight, Peter Redpath five,
George Drummond five and John James Redpath (1834-1884) three. ${ }^{42}$ Once again, provision was made for other Redpath sons to become partners, should they so wish. Most revealing was the amount of working capital invested in the refinery by each partner: John Redpath $\$ 207,218.20$, George Drummond $\$ 10,228.01$, Peter Redpath $\$ 7,879.44$, and John James Redpath $\$ 1,415.38$. One can only spreculate on the reasons for Peter's relatively low level of investment. Did the financial demands of his lifestyle or benefactions drain away his capital? What is clear, however, is the growing strength of George Drummond who would steadily emerge as the dominant partner. The years 1864 to 1866 , when Peter joined the McGill Board of Governors and gave the University his first gift of books, coincided with the end of the American Civil War and its attendant economic fluctuations: profits fell but assets increased so that the refinery was able to purchase bonds and stocks in other companies worth $\$ 158,054.37 .{ }^{43}$ Symbolic of the delicate relationship between Peter and George Drummond was the naming of the two ships launched by the refinery in 1866 after their wives: the "Grace Redpath "and the "Helen Drummond." 44

Despite the growing strength of George Drummond, in January 1868 the partners approved John Redpath's proposal that Peter succeed him as president. ${ }^{45}$ The elder Redpath's recognition of his advancing age and declining health was justified when, three months later, he suffered a serious stroke from which he never recovered, dying on March 5 ,

38 Tulchinsky, "John Redpath," 654.

39 Feltoe, Redpoth, 53, 56.

40 lbid, $55,56$.

41 Mackay, The Square Mile, 37-39.

42 Feltoe, Redpath, 59.

43 Feltoe, 71.

44 lbid., 71.

45 ibid., 71. 
1869. ${ }^{46}$ His death marked a fundamental turning point in the life of Peter, and the involvement of the Redpath family in the refinery. Towards the end of the year, Peter and Grace embarked upon a series of overseas tours, while still maintaining Montreal as their residence. Needless to say, this situation placed George Drummond in an awkward position as he was left to carry alone the bulk of the responsibility for running the refinery. As a result, the business underwent two fundamental reorganizations in the space of eight years. In 1871 , revised partnership articles divided the shares as follows: George Drummond 50\%, Peter Redpath $40 \%$ and Francis Redpath (1846-1928) 10\%. A clause in the agreement stated: "It is probable that Peter Redpath will be absent the greater part of the time." 47 Even so he continued on as president.

As with so many other aspects of his life, it is difficult to pin down exact details of Peter's activities during these years. Although he appears to have spent a great deal of time abroad, it would be a mistake to dismiss him as a mere dilettante, removed from the activities of his native city. From 1874 to 1881 , he served as president of the Montreal General Hospital and, from 1868 to 1882 , as a director of the Bank of Montreal, ${ }^{48}$ where he occupied himself greatly with early attempts to establish the Canadian Pacific Railway. He also served as a director of the Montreal Rolling Mills, Montreal Telegraph Co., the Inter-colonial Coal Co., and other mining companies, particularly in the Prairies. His unheeded warnings to Dawson to avoid mining speculation may have been motivated by unhappy personal experience.$^{49}$ Of course, he contin- ued serving on the McGill Board of Governors. The real issue appears to have been his unwillingness to participate in the operation of the refinery.

Peter's unwillingness might not have been so serious except that the 1870 s were a time of great difficulty for both the sugar industry and the Canadian economy. A major economic depression coincided with the tenure of the Liberal government of Alexander Mackenzie (1873-1878). His doctrinaire insistence upon free trade hit the sugar industry with a vengeance, as the industry required protective tariffs to face the competition of the much larger British, European, and American refineries. When Mackenzie's government reduced tariffs significantly, the Redpath refinery, along with virtually every other sugar refinery in the country, ceased operation in February $1876,{ }^{50}$ It should be pointed out that in that year the value of the plant was $\$ 600,000$ with the business requiring $\$ 2$ million in direct working capital and $\$ 1.5$ million in floating capital. ${ }^{51}$ Only with the return to office of Sir John A. MacDonald and the Conservatives, with their National Policy of protective tariffs for Canadian industry, did the refinery reopen in August 1879. At this point Drummond, who had borne the bulk of the responsibility during this nearly catastrophic period, insisted that the business be restructured as a public joint-stock company, which was done in June 1879. Although "Redpath" was retained as a trade label, the company name was changed to the Canada Sugar Refinery Company Limited. At the first meeting of the new company on August 1, Peter Redpath was elected president,

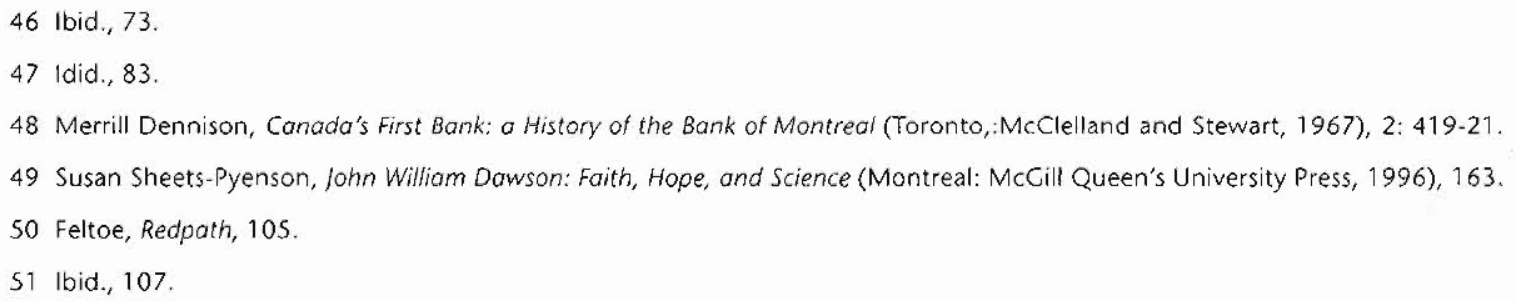


George Drummond vice-president and Francis Redpath a director. ${ }^{52}$

Not surprisingly, this situation proved untenable since Peter was no more willing to devote time to the refinery now than he had been during the preceding ten years. The advantage of having a Redpath provide continuity by serving as president was eventually outweighed for Drummond by the irritation he felt at doing all the work without gaining any recognition, particularly as real competition was now being faced from Dr. Alfred Baumgarten's St. Lawrence Sugar Refining Co., which began operations in Montreal that same year. ${ }^{53}$ In September 1879, Drummond succeeded Peter as president with Francis Redpath becoming vice-president, which position he held until 1883 when he reverted to the role of director ${ }^{54}$ Coincidentally in 1879 , Drummond's wife, Helen Redpath, died and he remarried the following year to Grace Parker Hamilton (1860-1942), which would have weakened the link with the Redpath family. ${ }^{55}$ By 1888 the annual profit had reached $\$ 773,727.47 .{ }^{56}$ In 1890 , serious consideration was given to an offer to buy the company's property and plant for $\$ 3$ million. ${ }^{57}$ Although Redpaths continued to hold positions of responsibility in the company until the First World War, the control remained firmly in the hands of the Drummond family until 1930. Under the impact of the great depression the company then merged with Dominion Sugar Co. to create the Canada and Dominion Sugar Co. ${ }^{58}$ Cordial personal relations between Peter Redpath and George Drummond appear to have continued despite their business deal- ings. After assuming the presidency, George would send annual letters to Peter discussing company business and current events. When Peter stepped down from his directorship of the Bank of Montreal in 1882, George succeeded him. Although Peter gave up his managerial role in the refinery and the bank, he continued owning their stocks.

We must assume that George's willingness to take charge of the refinery was exactly what Peter wanted, as he would now be relieved of its responsibility, and therefore able to develop a new life for himself. By 1882, Peter had divested himself of most of his business responsibilities, except for his directorship of the London board of the Bank of Montreal. Of course, he visited Montreal regularly and continued serving as a governor of McGill University. His real focus in life now became England, however, where he began studying law in London at the Middle Temple, joined the Council of the Royal Colonial Institute in 1886, and helped to found the Imperial Institute. In 1881, he purchased the Manor House in Chislehurst, Kent -a well-to-do community, only a short train ride from London. ${ }^{59}$ What were the factors that lead Peter to uproot himself in this way and begin a whole new life for himself in his sixties? One factor was that two of his brothers had also left the refinery to undertake other careers: George (18391877) in 1863 to join the Church of England clergy, and John James in 1868 to join the army, ${ }^{60}$ Another was the long standing desire of his wife Grace to retum to England. Most of all, one suspects that Peter, having fulfilled his duty to his father and the sugar refinery, was now intent upon fulfilling his own goals and

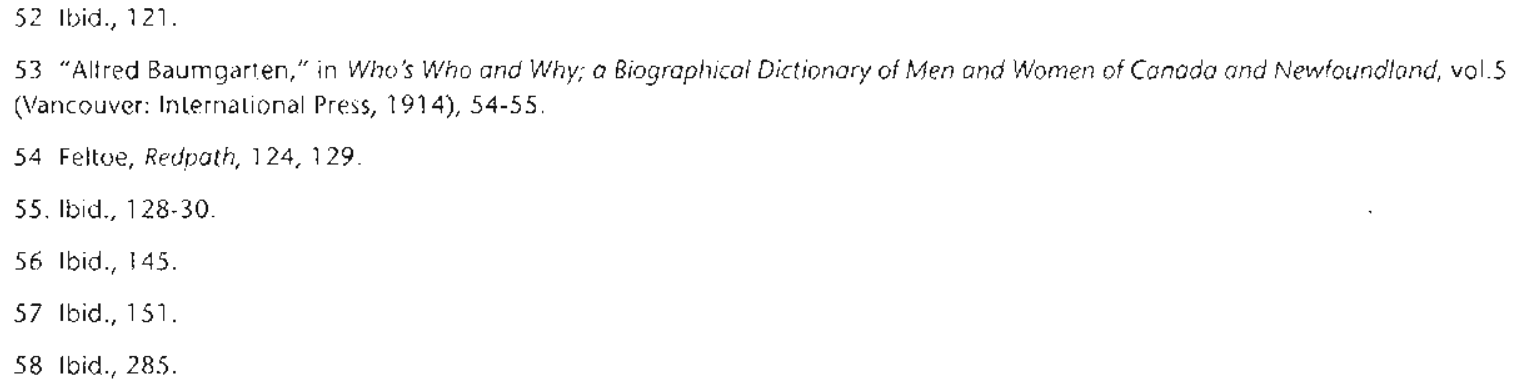


in the process those of Grace and Sir John William Dawson. Of course, the financial resources were more than sufficient; it seems likely, in the light of his subsequent collecting, benefactions, and life-style, that Peter may well have sold off many of his holdings at this time.

Given these various contexts, Peter Redpath's acceptance of a seat on the McGill Board of Governors in 1864 can be seen as contributing to a wide range of personal and communal agendas. As a wealthy and prominent businessman he was responding to a public responsibility. As an individual, he was satisfying an interest in culture and learning as well as a desire to be associated with an institution which interested him and with which neither his family nor George Drummond had any connection. In being offered a seat on the McGill board, he was receiving recognition of his status in the community. Dawson was particularly adept at enticing potential donors with the allure and prestige of a seat on the board and recognition for significant benefactions, such as named endowments and buildings. ${ }^{61}$ Of the major benefactors of his principalship - Peter Redpath, Lord Strathcona, and Sir William Macdonald-all were Scots or of Scottish descent, but had not attended McGill or any other university. In addition, Macdonald and Redpath were childless. Like Dawson, Redpath was also a Presbyterian. That these three, and countless athers, were so generous to McGill is a tribute to Dawson's effectiveness in dealing with benefactors, his unostentatious life-style, his charismatic personality and intellect, and his success in identifying the young institution with the goals of Montreal's anglophone elite.

This elite would have appreciated Dawson's utilitarian approach to higher education which emphasized science, technology, and the professions. Owens College in Manchester was his model for McGill. Also appreciated would have been Dawson's attempts to reconcile science and religion. ${ }^{62}$ His strongly voiced opposition to Darwin's theory of evolution, which did much to harm his scientific reputation, would have been welcomed by Peter Redpath and other benefactors whose religious views were generally traditional.

Peter's benefactions to McGill - like his father's began in 1856, the year after Dawson's arrival at McGill, when they both gave small amounts to the Principal's first subscription. ${ }^{63}$ Whereas his father's benefactions to the University remained quite small, Peter's grew steadily; over time his subscriptions to various funds would amount to $\$ 8,000.64$ With his election to the Board in 1865 , his benefactions began in earrest and the following year he gave a small collection of books to the library. Gifts of books would continue throughout his and Grace's lifetimes, and indeed, through their endowments, into the future. Peter's major benefactions occurred, however, only after the death of his father in 1869 and his subsequent disengagement from active business. The following year, he dorated $\$ 20,000$ for a chair of Natural Philosophy - or science - which, in 1893, he agreed to transfer to the Mathematics Department, where it remains to this day. 65 Between 1880-1882, as he concluded his business interests in Montreal and moved to England, he constructed the first of

S9 Arthur Battle, Edwardian Chistehurst: Memories of the Village Baker (Rainham, Kent: Meresborough, 1988); T. A. Bushell, Imperiot Chislehurst: the Story of a Kent Village, 3rd ed. Whittlebury, Eng.: Baron, 1997); E.A. Webb, The History of Chislehurst: its Church, Manors, and Parish (London: Allen, 1899).

60 Feltoe, Redpoth, $63,71$.

61 Sheets-Pyenson, John William Dawson, 51,57-63,72, 204-05; Allan Bell, "Munificent Wise and Thoughtful Gifts: Peter and Grace Redpath and the Redpath Tracts", Fontanus; from the Collections of McGill University VI (1993): 45-67.

62 Sheets-Pyenson, John William Dawson, 125-35.

63 Dawson, In Memoriam Peter Redpoth, 7.

64 Ibid., 38. 


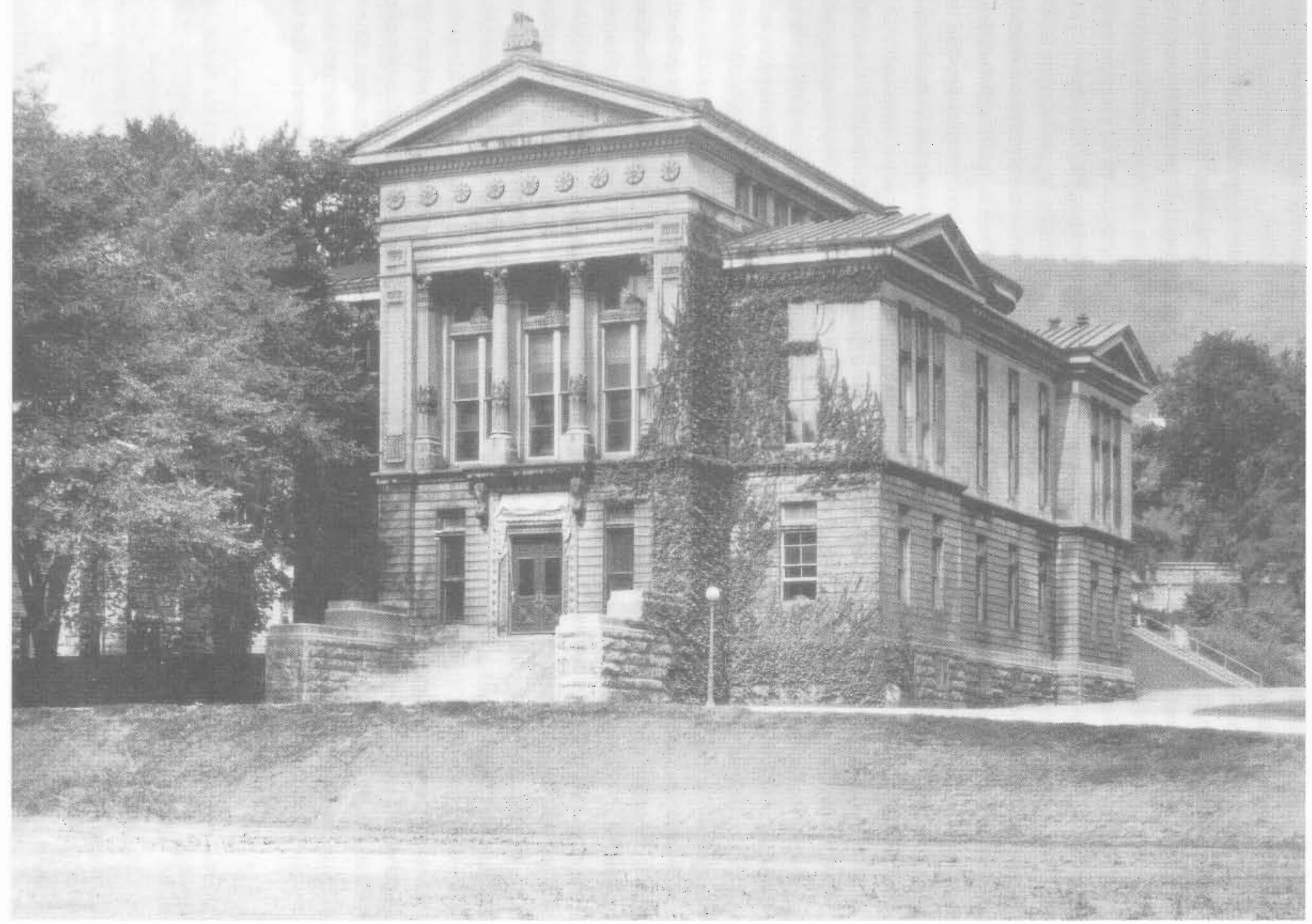


the two buildings that continue to bear his name. Redpath Museum (Fig. 3), designed by Hutchison and Steele and costing $\$ 140,000$, was built to house natural science collections and particularly Dawson's famous palaeontological collection. ${ }^{66}$ At a banquet on April 2, 1880 celebrating the twenty-fifth anniversary of Dawson's principalship, Peter announced his intention of building the Museum - which undoubtedly helped persuade the Principal to remain at McGili at a time when he considered leaving, due to the relocation of the Geological Survey of Canada from Montreal to Ottawa. Peter and Grace along with other members of the family figured prominently at the Museurn's inauguration by the Governor General, the Marquis of Lorne, during the 1882 Montreal meeting of the American Association for the Advancement of Science. Two years later, the British Association for the Advancement of Science was also enticed to meet in Montreal, largely because of the Museum. Peter supported the Museum with gifts of geological specimens and a grant of $\$ 1,000$ per year, increased to $\$ 1,500$ per year by the time of his death in 1894 . This rather modest sum was supplemented by grants that Peter encouraged from other people such as his friends, J. H. R. Molson and his wife.

The Redpaths' gifts of books began in 1864/1865 and can be divided into two major categories: the Redpath Historical Collection and the Redpath Tracts. The initial gifts were to the Historical Collection and described in an eight page catalogue published circa 1867, listing 185 titles in 617 volumes ${ }^{67}$ Although the collection would eventually include books on philosophy, theology, European, World and Canadian history, the primary focus of the collection would always remain British political and religious history. In 1865 the McGill Library contained only 5,000 volumes; consequently, the Redpath gift of 617 volumes would have been considerable. By 1884 , this Historical Collection had grown to 1784 volumes, as described in a catalogue published that year, ${ }^{68}$ still significant, since the library's total collection had only grown to 20,000 volumes. Additions to the Historical Collection continued to arrive annually or biannually from Peter and Grace until their deaths. As the books were primarily academic publications of the late nineteenth century, including the Calendars of State Papers and the Historical Manuscript Commission publications, they laid the foundations for McGill's reputation in the study of History, particularly British History.

The second category of books was the Redpath Tracts, considered the finest collection of its kind outside the British Library. Unlike the Historical Collection comprised of scholarly monographs, the Tracts were polemical in nature - pamphlets and brochures - published in Britain from the sixteenth century to 1900 . It is perhaps not accidental that the Tracts, so visceral and spontaneous, are counterpoised by an academic and scholarly Historical Collection. The Tracts arrived in three series. The first series containing 3,401 titles bound in 308 volumes, published between 1624 and 1860 - arrived at McGill in 1880 and is described at the end of the 1884 catalogue of the Historical Collection.$^{69}$ The second series - containing 3,587 titles bound in 582 volumes, published between 1558 and 1800 - was presented by

65 Ibid., 15 .

66 Susan Bronson, "The Design of the Peter Redpath Museum at McGill University: the Cenesis, Expression and Evolution of an Idea about Natural History," (Masters thesis, Université de Montréal, 1992); Rhodri Liscombe, "The Peter Redpath Museum, an Architectural Analysis," Fontonus, from the Collections of McCill University 1 (1988): 49-58; Sheets-Pyenson, John William Dawson, 57-58, 66-67.

67 A Catalogue of Historical Works Presented to the University of McGill College, Montreal, by Peter Redpath Esq. 1866. Collections, \&c (Cambridge, Printed for Macmillan \& Co. by I. Palmer, c. 1867)

68 A Catologue of Books Chiefly Relating to English and American History and Antiquities To-gether with a Collection of Historical, Ecclesiastical and Palitical Tracts (from 1642) Presented to the University of McCill College, Montreal by Peter Redpath, Esq. 1864-1884 (Cambridge, Eng.: Macmillan Bowes, 1884). 
Grace in 1901, coincidentally with the completion of a new wing to Redpath Library that she had funded. The titles are described in a separately published catalogue. ${ }^{70}$ The third series - containing 2,852 titles bound in 280 volumes, published between 1800 and 1900 - arrived at McGill two years later in 1903 and is also described in a separately published catalogue. ${ }^{71}$ It should be noted that 1,037 titles in 43 volumes of this third series were composed of scientific and engineering papers published or collected by Sir Charles William Siemens (1823-1883), a member of the famous German engineering family. ${ }^{72}$ All three series of Tracts were uniformly bound or boxed by the Redpaths in leather or buckram. The 9,840 Tracts are more or less evenly divided into three chronological periods: 1550 to 1700,1701 to 1800 , and 1801 to 1900. McGill has subsequently doubled the size of the collection by acquiring six additional series, many of which have been purchased from Redpath endowments. The Redpath Tracts are today the most important non-Canadian research collection in the McGill Library's Rare Books and Special Collections Division, and one of the most important to be found anywhere in the country. With the Historical Collection and the Tracts numbering between 15,000 and 20,000 books and pamphlets, the
Redpaths must be considered major bibliophiles, or book collectors.

As Peter Redpath's gifts of books continued through the 1880s, he came to realize that the facilities for housing them were certainly inadequate. Since 1862 the library had been quartered in various rooms of the newly built west wing (Molson Hall) of the Arts Building. ${ }^{73}$ By the late 1880 s these facilities had become insufficient for both books and readers. In fact, in 1887 Peter presented the library with an additional case for the Redpath alcove simply to house his growing gifts of books. ${ }^{74}$ As a result, in 1891 Peter offered to build a separate library building for McGill, which was designed by Sir Andrew Taylor and opened with great ceremony on October 30, 1893 by the Governor General, Lord Aberdeen. ${ }^{75}$ Redpath Library (Fig. 4) cost $\$ 135,000,{ }^{76}$ had a capacity of 140,000 volumes, and was built on land bought specifically for this purpose by J. H. R. Molson for \$42,500. In 1892, Peter agreed to contribute $\$ 4,000$ per year for the upkeep of the library and the librarian's salary, in addition to which he also contributed $\$ 500$ towards cataloging the library's collection. ${ }^{77}$ Peter also played a decisive role in the appointment of Charles Gould as the first University Librarian. ${ }^{78}$ Grace contributed $\$ 8,000$ from her own funds for the stained glass windows

69 A Catalogue of Books... 1884, 29-133.

70 Catalogue of a Collection of Historical Tracts, 1561-1800 in DLXXXII Volumes Collected and Annotated by Stuart I. Reid; the Gift of Mrs. Peter Redpath to the Redpath Library, McGill University, Montreal (London: Printed by the Donor for Private Circulation, 1901).

71 Catalogue of a Collection of Historical, Political, Economic, and Other Tracts and Brochures in Two Hundred and Eighty Volumes, 1800-1900, Arranged by Stuart J. Reid. the Gift of Mrs. Peter Redpath to the Redpath Library, McGill University, Montreal, 2 vols. (London: Privately Printed by the Donor, 1903).

72 H. T. Wood, "Sir Charles William Siemens," Dictionary of National Biography (London: Oxford University Press, 1921-1922), XVIII: 240-44.

73 Peter F. McNally, "McGill University Libraries," in Encyclopedia of Library and Information Science vol. 17 (New York: Dekker, 1976), 311-20.

74 McGill University Annual Report, 1887 (Montreal: McGill University, 1888), 18.

75 Peter F. McNally, "Dignified and Picturesque: Redpath Library in 1893," Fontanus, from the Collections of McGill University VI (1993): 69-84.

76 McGill University Archives. RG 4, C. 433, File $1351 \mathrm{E}$.

77 McGill University Annual Report, 1892 (Montreal: McGill University, 1893), 3. 


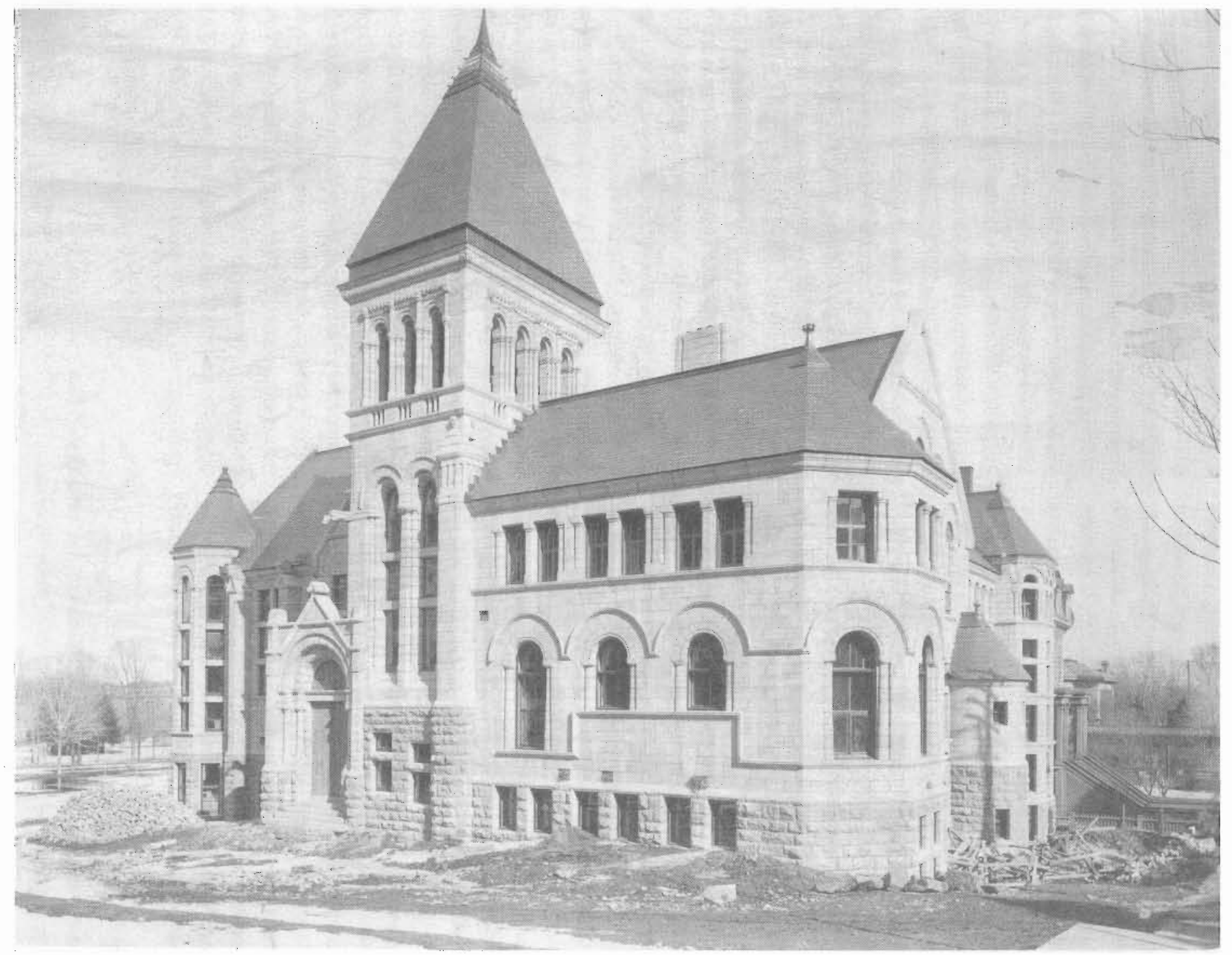

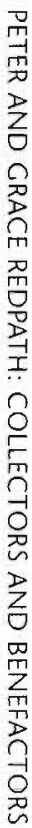

Figure 4. Redpath Library (1893). 
installed in the east and west ends of the library's impressive reading room.

These great benefactions proved to be Peter's last gitts to McGill. He died on February 1, 1894, three months after the Library's opening. It is important to note, however, that although he left his entire estate to Grace, he also made full provisions for the disposition of his estate should she have predeceased him. ${ }^{79}$ In addition to innumerable family bequests, $\$ 150,000$ would have gone to McGill: $\$ 100,000$ to the library, $\$ 30,000$ to the museum, and $\$ 20,000$ to the office of the Principal. As a further point of interest, it was understood within the family that, had he lived a few months longer, Peter's benefactions would have been acknowledged by his being created a baronet in Queen Victoria's birthday honours list.

In any event, Grace continued her husband's work. She maintained the Museum's annual operating grant of $\$ 1,500$, but the Library's grant was increased to $\$ 5,000$ in 1895 , to $\$ 6,000$ in $1901 / 02$, and to $\$ 10,000$ in $1902 / 03$. By comparison, it is noteworthy that the entire endowment income of the Faculty of Medicine, in $1904 / 05$, was also $\$ 10,000$. In 1894 she supplied the funds for purchasing additional steel fixtures for the library stacks; in 1901 she supplied $\$ 52,000$ for building an extension to the stack wing. ${ }^{80}$ In addition she gave grants for cases, shelves, and tables. Annual gifts of books continued throughout her lifetime. In a small but highly symbolic innovation, she changed the name on the Redpath book-plates, inserted on separate fly-sheets in each volume, from "Peter Redpath "to "Peter and Grace Redpath." On her death, January 301907 , the value of Grace's Canadian holdings alone was nearly
$\$ 1,000,000$; no estimate is available of her British holdings. ${ }^{81}$ Although the bulk of her estate was divided among a wide range of Redpath and Wood family members, she left McGill $\$ 150,000$ in the form of Bank of Montreal shares: $\$ 120,000$ ( $\$ 20,000$ more than Peter had earmarked) for the library and $\$ 30,000$ for the Museum. ${ }^{82}$ Elimination of the bequest to the principal's office suggests that Grace had probably not enjoyed the same close, personal relationship with Sir William Peterson (1856-1921) that she and Peter had enjoyed with Dawson. Although the income from these endowments continues to the present, concern was expressed at the time that at a $4.5 \%$ return the amount left for the library would yield only $\$ 5,400$, or $\$ 4,600$ less than her annual grant. ${ }^{8.3}$ Circumstantial evidence suggests that the shortfall was probably made up by Sir William Macdonald.

An intriguing aspect of the will is a sentence stating that, in addition to Grace's inheritance from Peter and money saved since his death, the estate also included what had been "acquited from other sources." An implication of having money of her own always accompanied Grace. To the family's amazement, Grace's mother-in-law Jane Redpath died on the same day. With the death of these two old protagonists, each vowing to outlive the other, a divisive family feud was finally laid to rest. That Peter and Grace enjoyed the support of at least some members of their family is best shown by the other Redpath family endowments given to the Library: Alice $\mathrm{E}$. Redpath, P. W. \& J.C. Redpath, William Wood Redpath, and Sir Thomas and Lady Roddick. The

78 McCill University Board of Governors' Minutes. 17 June $3892 ; 24$ June 1892.

79 Peter Redpath. Wil:, October 28, 1892. Great Britain, Public Record Office.

80 MeCill University Annual Report, 1895, 6: Annud Report, 1897, 18; Annual Repont, 1898-99, 27; Annual Report. 1899-1900, 5, 10; Anmual Report, 1900-01, 3; Anmual Report, 1901-02, 22; Anmwal Report, 1902-03, 8, 12; Annual Report, 1904-05, 2

81 "Lıst of assets of the late Mrs. Grace Wood Redpath in Canada, estimated value on 30th af January 1907" [Undated, typed document belonging tó Linda Redpath, Victoria, B.C.]. 
Redpath endowments had a capital value in 1995 of approximately $\$ 1.5$ million. ${ }^{\text {st }}$

These collections and benefactions beg fundamental questions: why did Peter and Grace Redpath collect and why did they make such substantial gifts to McGill? Of course, the collections might be dismissed as the playthings of wealthy and idle people, who were merely attempting to distinguish themselves from other merchant princes, particularly their rival Sir George Drummond and his art collection. Similarly, their benefactions to McGill might likewise be dismissed as monuments to the conspicuous display of wealth and social prominence of a couple desiring to assert themselves within a small, closed society. Although the elite nature of the collections and benefactions must be fully acknowledged, neither of these interpretations is ultimately satisfying or bears close scrutiny. The books are at once too scholarly in the case of the Historical Collection or too radical in the case of the Tracts to be considered mere playthings. In addition, the various bernefactions of money, books, and buildings assumed their monumentality only after 1880 , when Peter and Grace had moved to England. If social distinction had been their real aim, they could have made their benefactions in Britain where Peter's baronetcy would have been completely assured.

It would seem instructive, therefore, to consider the motivation of the Redpaths in their own terms. Looked at one way, the collections and benefactions can be placed into three obvious categories: books, buildings, and other. Into the "other" category, can be placed Peter's various monetary subscriptions to McGill and the endowed chair. Into the "building" category, can be placed Redpath Museum and Redpath Library and their endowments. As for the "books", to this category belong the 15,000 to 20,000 books and pamphlets of the Tracts and Historical Collection, along with their endowments.

Looked at another way, the collections and benefactions can be placed into three broad subject areas - history, religion, and science - with a particular focus upon Britain. Concerning the scientific collections and benefactions - Redpath Museum, the Redpath chair, and the Siemens Collection - a number of motivations suggest themselves. The fact that the Redpath fortune was largely based upon sugar refining, which in turn was highly dependant upon technology, may well have predisposed Peter towards science. Equally important if not more so, however, would have been the Redpaths' friendship with William Dawson. His status as Canada's leading scientist, along with his ambitions for the University, would have been major factors in these benefactions. Finally, there is the enormous prestige paid to science throughout the nineteenth century. ${ }^{85}$ In supporting science, the Redpaths were simply identifying themselves and McGill with one of the great intellectual movements of the age. That said, it should be noted that Mrs. Redpath showed relatively little interest in the scientific collections and benefactions. Although she gave the Siemens Tracts, they were not individually listed in the published catalogue of the third series of the Tracts, of which they form a part. As for the Museum, although she treated it in her lifetime and in her will as generously as Peter had, she paid it no particular attention and did not increase the amounts designated by her husband.

82 Grace Redpath. Will, 19 February, 1902. First Codicil, 25 April, 1902; Second Codicil, 30 June, 1902; Third Codicil, 5 January, 1904; Fourth Codicil, 29 April, 1904; Fifth Codicil, 17 January, 1905. Great Britain, Public Record Office.

83 McGill University Annual Report, 1906-1907 (Montreal: McG Ill University), 19.

84 Information supplied by the McCill Universisy Treasury Department

85 Walter E. Houghton, The Victorian Frame of Mind, 1830-1870 (New Haven: Yale University Press, 1957), 33-36. 
Concerning the historical and religious collections and benefactions, one comes face to face with Peter's and Grace's core values and joint concerns. For it is obvious that history and religion were shared passions that engaged their hearts and minds, both as people and as collectors and benefactors. To begin with, it is not clear that these collections were assembled with any particular concern for the academic ambitions of Dawson and McGill. History would be taught as a separate subject only after 1895, and religion only after $1948 .^{86}$ What is clear, however, is that after Peter's death the books in these subjects continued coming to McGill in even greater numbers than before. A case in point is the Tracts, the bulk of which came after his death. Grace's role in collecting them is made explicit in their continuing chronologically until 1900 , despite Peter's death in 1894. Other indications of Grace's involvement with the Redpath books can be seen in her alteration of the bookplate to include her name along with Peter's, and her continuing gifts to the Historical Collection. Some of the reasons for the Redpath's interest in history and religion can be gleaned from the details of their lives, thereby compensating for the lack of any explicit statements from them about this or most other topics. Their interest in religion is reflected in many ways. Despite being married and buried in the Church of England, they were both from Protestant non-conformist backgrounds: he a Presbyterian and she a Methodist. Both in their public and private lives, the importance of religion can be noted. After Peter's death, Grace supported the establishment of a Presbyterian church near Chislehurst. ${ }^{87}$ Beyond these personal considerations, recognition must be paid to the centrality of religion in Victorian England. ${ }^{88}$ As for history, one cannot help but think that the collections began as a way of helping Grace counteract her homesickness for England. Anglophilia is one of the constant elements in their lives. In addition to any personal interest in history, there is the general preoccupation of the Victorian era with historical study ${ }^{89}$ Taking history and religion together, their intertwining role in the political process - in both Britain and Canada - has been pointed out by many commentators. Through their collections, the Redpaths were once again identifying themselves and McGill with the great intellectual movements of the century.

It is with the library that the shared enthusiasm of the Redpaths becomes manifest. Although Peter and Grace may have appreciated the study and research role of the library, its role as a home for their books is probably their real motivation for building it. Whereas the Museum is designed in the style of a Graeco-Roman temple and has few mementos of its benefactors (except for a large portrait of Peter), the Library's reading room is designed in the style of a Christian church and is filled with mementos of both Redpaths. The Christian symbolism of the building is considerable and would have been wholly in conformity with the wishes of the benefactors. Grace's emotional attachment to the Library is evidenced in the construction of the stack wing (1901), the gifts of books, the steadily increasing annual grants, and the increased bequest in her will. Most emblematic of Grace and Peter's commitment to the Library was the gift from her own funds of stained glass windows for the reading room. Following Peter's death, she had added a further band of stained glass across the bottom of the east windows. Along with portraits of the two of them, it contains an inscription in Latin, which reads: "Vitream Istam Cura Sua pictam Collegio Mariti Gratia Amato Dono Dedit Gratia

86 Stanley Brice Frost, McGill University for the Advancement of Learning, vol. 2 (Montreal: McCill-Queen's University Press, 1984), 30,289 .

87 "The Late Mrs. Redpath," The Bromiey Chronicle, February 7, 1907, 5.

88 Houghton, The Victorion Frame of Mind, $21 \mathrm{n.77}$

89 David Newsome, The Victorian Worid Picture: Perceptions and introspection in an Age of Change (London: Fontana, 1998 ), 142. 
Redpath" ("Grace Redpath Gave This Stained Glass Window to the College at Her Own Expense in Commemoration of Her Beloved Husband").

In the light of this remarkable saga of collecting and benefaction, it seems only right to conclude this story with several general acknowledgements. To begin with, Peter and Grace Redpath deserve acknowledgement as Canada's first great benefactors of libraries and museums as well as being amongst our first great bibliophiles and benefactors of higher education. Next, Grace Redpath must be acknowledged as the first woman in Canada to be a major benefactor of a library, museum, or university as well as being one of the first Canadian women to be a major bibliophile. Finally, it should be acknowledged that in their collecting and benefactions, the Redpaths allied themselves and McGill University with the three most powerful intellectual movements of the nineteenth century: science, history, and religion.

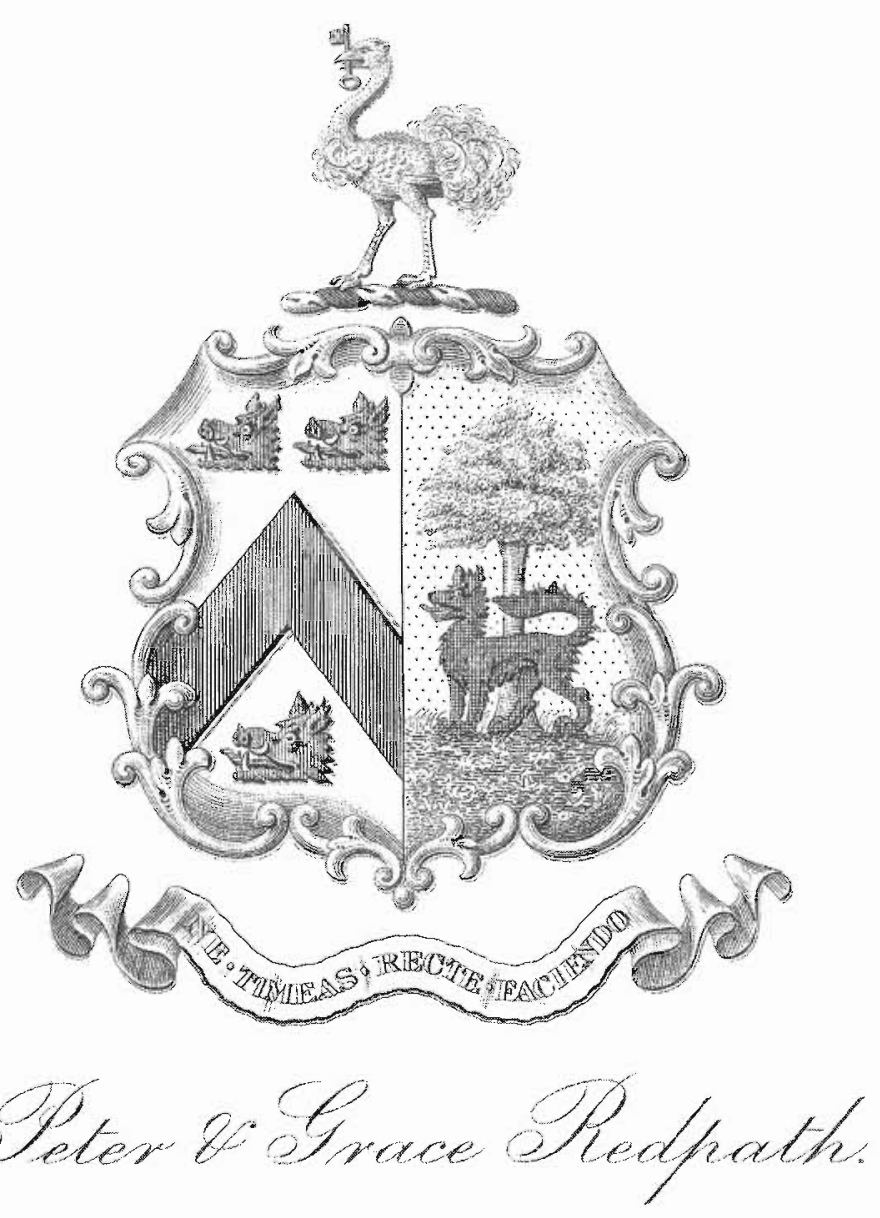

